\title{
DEVELOPMENTS IN DESIGN OF WOOD STRUCTURES FOR EARTHQUAKE RESISTANCE
}

\author{
Andrew H. Buchanan*
}

\author{
This paper was presented at the Fourth Canadian Conference \\ on Earthquake Engineering, Vancouver, B.C. Canada, in June \\ 1983
}

\begin{abstract}
:
This paper briefly describes the major factors affecting the behaviour of wood structures in earthquakes. Recent developments in timber engineering have resulted in increasing interest in wood as an engineering material, which is being extended to earthquake resistance of wood structures, particularly in New Zealand. This paper suggests how recent advances in timber engineering and earthquake engineering can be combined to produce improvements in the design of wood structures for seismic regions.
\end{abstract}

\section{PERFORMANCE OF WOOD STRUCTURES IN EARTHQUAKES:}

Wood structures have a good reputation for earthquake resistance, and have fared much better than many other building materials in many major earthquakes. The good performance of wood structures in Asia and South America which have withstood earthquakes for hundreds of years is attributed to flexible connections where energy is absorbed with wood yielding in compression perpendicular to the grain, assisted by torsionally symmetrical designs (22).

In a review of earthquake damage and structural performance for all types of structures in the U.S. (42), small wooden buildings performed remarkably well. Even in major earthquakes most of the wood structures suffered damage considerably less than $5 \%$ of the building's value. Damage generally consisted of cracking of partitions, moving off foundations or unreinforced chimneys falling through roofs. In the Alaska and San Fernando earthquakes (20), building failures were generally associated with torsionally unsymmetrical designs.

New Zealand experience (13) shows a similar pattern of earthquake damage. Japanese buildings have also suffered from the absence of diagonal bracing, and excessive notching of moment-resisting columns at critical connections (4). In the 1964 Anchorage earthquake there were many examples of wood frame buildings remaining intact despite massive earth movements (1).

\section{MATERIAL PROPERTIES AFFECTING SEISMIC}

\section{DESIGN:}

Weight -

The most prominent advantage of wood as an earthquake-resisting material is its light weight and high strength to weight ratio compared with other materials. Thi light weight combined with high damping,

*University of British Columbia, Canada results in greatly reduced inertial forces, requiring a smaller lateral force resisting system.

Ductility -

A fundamental objective of earthquake resisting design is the prevention of brittle failures. In wood structures these can occur in tension, bending or shear. Wood exhibits ductile behaviour in compression, but it is not easy to utilize this behaviour in design. The possibility of reinforcing wood members with steel to eliminate brittle tension failures deserves more attention (24).

Variability in strength -

The strength of wood is very variable and cannot be accurately predicted using non-destructive test methods. current moves away from small clear testing to in-grade testing $(10,27)$ will result in much more reliable design stresses. The variability of strength between wood members means much higher design stresses if several members share the load. Load sharing is inadequately allowed for in the current Canadian code. Load sharing and duration of load have received recent attention for gravity loads (18) but not for earthquake loading.

\section{Size Effects -}

In brittle materials such as wood, large members have lower strength than similarly loaded smaller members. This size effect has been investigated for bending (7), shear (19), tension perpendicular to the grain and in connections (5). Size effects, which are not yet fully understood, create problems in predicting tension strength from bending tests, or extrapolating from small test specimens to large members.

\section{Duration of Load -}

The decrease in strength of wood members under long term loading is receiving considerable attention $(6,21)$. The traditional curve for estimating duration of load effects (10) indicates 
very high increases in strength for short duration of impact loading. An experimental study (36) shows that the lower 5 th percentile bending strength of commercial lumber is essentially constant for failure times ranging from 1/50th second to 100 hours. This suggests that design stresses for earthquake loading should be based on short duration tests (time to failure 5 minutes or less) with no modification for duration of load. A difficulty in proposing a duration of load factor is that an earthquake after, say, 50 years may find the strength of the member or connection reduced due to accumulated damage from dead load. live load or minor earthquake loads. The effect of duration of load or loading rate on the strength of connections is unknown, although an increase in stiffness under vibrational loading has been reported $(48)$.

\section{Moisture Content -}

Recent in-grade testing (28)

indicates that as commercial lumber dries the ratio of tension to compression strength decreases, increasing the possibility of a brittle tension-dominated failure in bending. Another problem is the transverse shrinkage and swelling that takes place under fluctuating moisture conditions which can create problems with connections where wood is under restraint perpendicular to the grain.

\section{Fire Resistance -}

Heavy wood construction exhibits much better fire behaviour than unprotected steel. In New Zealand, recent code changes (37) allow all-wood construction to four storeys for commercial and residential buildings with sprinklers. Fire resistance for floors and structural members may be calculated on the basis of charring rate and level of load $(26,38)$, providing a more rational design than Canadian "heavy timber construction" (31). The fire performance of connections has received little attention, but indications are that unprotected nail and nail-plate connections perform very poorly (25).

\section{DYNAMIC RESPONSE OF WOOD STRUCTURES:} that:

The new New Zealand code (39) states

"In determining the effect of earthquakes on timber structures, due consideration shall be given to the likely response of the structure, its potential for energy absorption, level of damping, and possible mode of failure."

These objectives are excellent, but the knowledge to meet them is not readily available.

\section{Structures with Rigid Connections -}

The dynamic response of rigidly connected wood structures (such as curved glulam arches, finger-jointed rigid frames or glued diaphragms) will be similar to any other linear elastic structures. It is not possible to utilize the ductile compression behaviour in bending without running the risk of a brittle tension failure. A small height building will have a short period of vibration despite the low Young's modulus of wood. Damping is likely to be low, in the same range as other materials. A wood structure with strong rigid connections is a poor structure for earthquake resistance because it must be designed for a fully elastic response to the largest expected earthquake if a brittle failure is to be avoided. This willresult in very large members compared with those of ductile materials or a design with yielding connections.

\section{Structures with Yielding Connections -}

A more desirable form of wood construction has connections that are capable of absorbing energy in reversed cyclic loading. This category includes nailed plywood shearwall buildings, nailed or other moment-resisting connections using steel plates, and some bolted connections. The connections are of prime importance in these structures. They must be strong enough for the building to remain intact throughout the earthquake, yet be able to yield before any brittle wood failure occurs, and be able to dissipate a large amount of energy through hysteretic and damping behaviour.

\section{Damping -}

The level of damping significantly affects seismic response. In plywood shearwalls, Medearis (29) found a high level of frictional damping equivalent to 6 to $10 \%$ of critical viscous damping. Dowrick (15) suggests increasing this figure to $15 \%$ to allow for damping in other parts of the structure. Other studies of completed one and two storey buildings (20) found damping between $4 \%$ and $6 \%$ and natural frequencies of 4 to $18 \mathrm{~Hz}$. Chopra and Newmark (12) recommend 5 to 7\% damping for wood structures at working stress levels, increasing to 10 to $15 \%$ for bolted joints and 15 to $20 \%$ for nailed joints at yield load levels. The upper figures quoted above are very high compared with other materials. If correct they indicate that wood structures can dissipate a larger amount of energy through damping, which will result in considerably lower amplification factors for design purposes.

\section{Ductility -}

Modern earthquake design codes ( 31 , 41) prescribe certain lateral loads for structures that possess "adequate" ductility, and much larger loads for structures with little or no ductility. Structures are deemed to have adequate ductility if the whole structure can undergo a number of load reversals with horizontal deflections considerably larger than at first yield. Unlike steel, many wood connections exhibit curvilinear load deflection relationships at low load levels, and considerable softening after a number of load reversals leading to pinched hysteresis loops. It is difficult to define ductility factors in the normal way for this type of connection. An alternative possibility is to assess ductility on 
the basis of the area enclosed by hysteresis loops from reversed cyclic testing (43).

\section{Code Requirements -}

The Canadian code (31), specifies lateral loads proportional to a " $K$ " factor which allows for different structural types and materials. In comparison, the New Zealand code (4I) has a similar "SM" factor which is more clearly defined for wood systems. These are summarized in Table 1, showing that design loads for wood are similar to other materials for walls, but considerably larger for frames. New zealand requirements for braced systems are much larger than Canadian requirements. The New Zealand figures quoted for wood structures have been based on somewhat arbitrary judgement, but create more guidance to designers than is available in the Canadian code. Much further research is necessary before the seismic response of wood structures can be predicted with accuracy on the basis of stiffness, ductility and damping.

\section{WOOD STRUCTURAL SYSTEMS AND COMPONENTS:}

\section{Shearwall and Diaphragm Systems -}

Most wood frame structures utilize diaphragm and shearwall behaviour to resist lateral loads $(8,45)$. The most common sheathing is plywood or other wood-based panel product, with ductile nailed connections capable of resisting reversed cyclic loading. Shearwall and diaphragm construction has proved to be an excellent structural system, and has been the subject of many publications. An extensive bibliography on research to 1975 (11) included very little analysis or testing under cyclic loading. More recently finite element techniques have been developed for analysis of shearwalls $(16,17)$, and considerable diaphragm testing has been carried out (46) but most studies have not included the effects of cyclic loading. Overall wall rotation due to base flexibility has not received sufficient attention.

Recent workshops have described current studies (2) and identified research needs for this type of construction (20). Very high priority is given to three-dimensional structural analysis of houses and dynamic shear panel tests, as well as several more practical suggestions. In New Zealand a more direct approach is outlined in a new code (40) which specified wall bracing requirements for small buildings in terms of "bracing units", which are defined with reference to a standard cyclic testing procedure (41).

\section{Diagonally Braced Systems -}

A variation on the shearwall system is a wood frame wall with lateral loads carried by diagonal bracing rather than continuous sheathing. For small buildings the bracing can be a wood member notched into the studs or light metal strap or angle bracing. In theory such a system can perform the same function as plywood sheathing, but problems arise because lateral forces are concentrated in a much smaller area with far fewer energy absorbing connections, and it can be very difficult to make end connections of sufficient strength. Diagonally braced systems become sloppy after reversed loading if they are not capable of yielding in both tension and compression.

\section{Moment Resisting Frames -}

Moment resisting frames from glued laminated wood have exciting potential for wood structures, and have become popular in New Zealand, particularly for single storey portal frame industrial buildings (9). The key to this form of construction is a simple nailed beamcolumn connection using steel side plates as shown in Figure 1. This type of connection can be made strong enough to exceed the ultimate strength of the glulam members, but for earthquake resistance it is intentionally designed to be the weakest link in the structure. There are two possible design approaches. The first approach is to use strong steel side plates with the weakest link being the nails. The nailed connection typically exhibits ductile behaviour under cyclic loading with some decrease in strength and stiffness after a number of cycles. The hysteretic behaviour of this type of connection has been studied in some detail (23). The second approach is to under-design the steel plate so that it undergoes ductile flexural yielding with no distress in the wood members or the nails (44). The response of this system becomes essentially that of a steel frame structure.

Similar possibilities are available with different configurations, possibly using glulam rivets, but no studies have been made on the behaviour of glulam rivets under reversed cyclic loading. Another type of connection with potential for moment resisting frames is deformed steel reinforcing bars or threaded rods glued into drilled holes with epoxy adhesives (34). These bars could be used to connect large glulam members together with steel connecting plates specially designed to make ductile flexural connections.

The types of connection described here have potential for multi-storey moment-resisting frame structures 3 or 4 storeys high, although none have yet been constructed. Potential problems with this type of construction include large member sizes, limiting shear stresses in columns, and large inter-storey deflections. Lateral deflections may dictate larger structural members to increase stiffness, possibly to the extent that earthquake loads can be resisted in the elastic range. It is much more likely that multi-storey wood structures will rely on shearwalls, cross bracing, or other materials for lateral load resistance.

\section{Glulam Shearwalls -}

The possibility of solid wood shearwalls from glued laminated wood has not been properly investigated, but deserves consideration. In reinforced 
concrete construction, the lack of stiffness and high cost of moment-resisting frames has led to more emphasis on cantilever shearwalls and eventually to the excellent coupled shearwall system (32). The same options are possible in solid wood construction, using structural steel or other energy absorbing devices at the bases of cantilever glulam shearwalls, and ductile steel coupling beams between solid wood walls. There are many possibilities deserving consideration.

\section{Other Materials -}

A compromise solution to overcome the inadequacies of wood as an earthquake resisting material, is to create a wood structure where lateral loads are resisted by more conventional materials such as steel or reinforced concrete. Such a system can be very economical because it results in a very light weight structure with efficient use of all materials. This is particularly suitable if exterior fire walls or a service core are required to be of concrete. An example of this type of construction is a recent 4 storey, 3900 $\mathrm{sq} . \mathrm{m}$. Office building in New Zealand where a reinforced concrete core resists all lateral loads and provided lateral stability during construction. The floors are all solid wood decking supported on glulam beams and columns (35).

\section{Foundations -}

As with any structure, lateral load resisting elements can only be effective if they can transfer forces to the ground through an adequate foundation system. There are many reports of damage to wood buildings due to inadequate foundations or foundation connections (42). Pole frame structures with cantilever poles require special consideration, particularly on steep hill sites where differential stiffness can create torsional problems. Slender shearwalls with low gravity loads and high overturning moments require special connections and additional tension capacity in the foundations if they are to behave as intended. Detailed recommendations for lateral stability of foundation systems for small buildings are available $(40)$.

\section{Connections -}

The fundamental importance of good connection details has been referred to several times. Most structural failures in wooden buildings can be attributed to poor connection details $(13,42)$. Design loads for connections are generally derived either by applying a safety factor to a failure load under test, or by specifying the load at some particular level of deformation. Most building codes give no indication of which criterion was used, making it almost impossible for a designer to estimate ultimate load capacity (47). This is a major obstacle in the development of a rational design procedure. of particular importance is the integrity of floor and roof diaphragms and their connections to lateral load resisting elements. Forces at these junctions can be very high. Poor connections of wood floors or roofs to concrete walls have led to failures (20) and require careful detailing (8).

\section{FUTURE DIRECTIONS:}

Only little progress has been made towards an overall design philosophy for wood structures subjected to earthquakes $(3,30)$. Much can be learned from developments in reinforced concrete design. Design methods must allow for some damage as a result of ductile post-elastic behaviour in moderate earthquakes, but an overriding criterion is that the structure will survive the largest expected earthquake without collapse (33). Design is then based on a "capacity design philosophy" whereby a desirable and acceptable heirarchy in the development of energy dissipating mechanisms is chosen, and each member and connection is provided with sifficient strength to ensure that behaviour (4I).

This paper has outlined many of the areas in which insufficient information is currently available to propose such a design procedure for wood structures. Important progress has been referred to, but much needs to be done, particularly with reference to the dynamic response of wood structures and the ultimate load behaviour of many types of connection details under seismic loading. These subjects are beginning to receive increasing attention, particularly in New Zealand (43) and there is great scope for future developments.

\section{REFERENCES :}

1. Anderson, L.O. \& J.A. Liska. Wood Structure Performance in an Earthquake in Alaska. USDA for. Serv. Res. Paper FPL 16, 1965.

2. Applied Technology Council. Proceedings of a Workshop on Design of Horizontal Wood Diaphragms, Palo Alto, ATC Publication 7-1, 1981 .

3. Applied Technology Council, Tentative Provisions for the Development of Seismic Regulations for Buildings. Chapter 9., ATC Publication 3-06, 1978 .

4. Architectural Institute of Japan, Design Essentials in Earthquake Resistant Buildings, Elsevier Publishing Company, New York, 1970.

5. Barrett, D.J., R.O. Foschi \& S.P. Fox., Perpendicular to Grain Strength of Douglas-Fir., Can. J. Civ. Eng., 2: 50-57, 1975.

6. Barrett, D.J. \& R.O. Foschi. Duration of Load and Probability of Failure in Wood. Parts I \& II Can. J. Civ. Eng., 5:505-532, 1978.

7. Bohannon, B. Effect of Size on Bending Strength of Wood Members. USDA, For. Serv. Res. Paper FPL 56. 1966 .

8. Breyer, D.E. Wood Structures McGraw Hill, New York, 1980. 
9. Bryant, A.H., J.A. Gibson, T.N. Mitchell, \& S.J. Thurston, Nailed Moment Joints in Timber Structures, Bull. N.Z. Nat. Soc. Earthquake Eng. 14(4), 1981.

10. Canadian Standards Association, Code for Engineering Design in Wood. CAN3-086-M80. 1980.

11. Carney, J.M. Bibliography on Wood and Plywood Diaphragms. Proc. ASCE. 101 (STIl):2423-2436. 1975 .

12. Chopra, A.K. \& N.M. Newmark, Analysis Chapter 2 of Design of Earthquake Resistant Structures (E. Rosenblueth, Ed.) John Wiley and Sons, New York, 1980 .

13. Cooney, R.C. The Structural Performanance of Houses in Earthquakes. Bull. N.Z. Nat. Soc. Earthquake Eng. 12(3):223-237, 1979.

14. Cooney, R.C. \& M.J. Collins, A. Wall Bracing Test and Evaluation Procedure Technical Paper P21. Building Research Association of N.Z. 1979.

15. Dowrick, D.J. Earthquake Resistant Design. John Wiley and Sond, London 1977 .

16. Easley, J.T., M. Foomani \& R.H. Dodds. Formulas for Plywood Shear Walls. Proc. ASCE 108(STII): 2460-2478. 1982 .

17. Foschi, R.O. Analysis of Plywood Diaphragms and Trusses. Part I : Diaphragms. Can. J. Civ. Eng., $4: 345-352 . \quad 1977$

18. Foschi, R.O. Structural Analysis of Wood Floor Systems. Proc. ASCE 108 (ST7) : 1557-1574. 1982

19. Foschi, R.O. \& J.D. Barrett. Longitudinal Shear Strength of Douglas-Fir. Can. J. Civ. Eng., $3: 198-208$. 1975 .

20. Gupta, A.K. (Ed.) Seismic Performance of Low Rise Buildings, State-of-theArt \& Research Needs. Proc. Workshop at Illinois Inst. Tech. 1980 ASCE 1981.

21. Johns, K.C. and B. Madsen, Duration of Load Effects in Lumber. Parts I, II, III. Can. J. Civ. Eng., $9: 502-536$. 1982 .

22. Keenan, F.J. The Earthquake Resistance of Timber Construction. Proc. Int. Conf. on Eng. for Protection from Natural Disasters. Asian Inst. Technology, Bangkok. 1980.

23. Kivell, B.T., P.J. Moss \& A.J. Carr, Hysteretic Modelling of MomentResisting Nailed Timber Joints. Bull. N.Z. Nat. Soc. Earthquake Eng. $14(4): 233-243$. 1981 .

24. Krueger, P.G. Ultimate Strength Design of Reinforced Timber. Wood Sci. 6(2): 175-187. 1973.
25. Leicester, R.H., C.A. Seath \& L. Pham. The Fire Resistance of Metal Connectors, Proc. 19th For. Prod. Res. Conf. Australia, 1979 .

26. Lie, T.T. A Method of Assessing the Fire Resistance of Laminated Timber Beams \& Column. Can. J. Civ. Eng. 4:161-169. 1977.

27. Madsen, B. In-Grade Testing Problem Analysis. For. Prod. J. $28(4): 42-50 . \quad 1978$.

28. Madsen, B. Recommended Moisture Adjustment Factors for Lumber Stresses. Can. J. Civ. Eng. Accepted for Publication 1982 .

29. Medearis, K. Structural Dynamics of Plywood Shear Walls. Wood Sci. $3(2): 106-110.1970$.

30. Mitchell, T.N. Seismic Design of Timber Structures. Proc. South Pacific Regional Conference on Earthquake Engineering. pp. 716-740 Wellington, N.Z. 1979 .

31. National Building Code of Canada. National Research Council, 1980.

32. Park, R. \& T. Paulay, Reinforced Concrete Structures, John Wiley and Sons, New York, 1975.

33. Paulay, T. Developments in the Seismic Design of Reinforced Concrete Frames in New Zealand. Can. J. Civ. Eng. 8:91-113, 1981.

34. Riberholt, $\mathrm{H}$. Steel Bolts Glued into Glulam. Proc. IUFRO Wood Engineering Group S5.02. Oxford, U.K. 1980 .

35. Smith, P.C., Design Aspects of a Four storey Timber Building. Newsletter N.Z. Timber Design Society. 8:7-28, 1982 .

36. Spencer, R. Rate of Loading Effect in Bending for Douglas-Fir Lumber. Proc. First Int. Conf. on Wood Fracture. pp 259-279. Forintek Canada Corp. Vancouver, B.C. 1979.

37. Standards Association of New Zealand. Fire Resisting Construction and Means of Egress. NZS 1900 Chapter 5, 1978.

38. Standards Association of New Zealand. Fire Resistance Rating of Load Bearing Timber Elements. MP $9 / 8: 1980$.

39. Standards Association of New Zealand. Code of Practice for Timber Design. NZS 3603:1981.

40. Standards Association of New Zealand, Code of Practice for Light Timber Buildings Not Requiring Specific Design. NZS 3604:1978. 
General Structural Design and Design Loads for Buildings. NZS 4203:1976.

42. Steinbrugge, K.V. Earthquake Damage and Structural Performance in the United States, Chapter 9 of Earthquake Engineering (R.L. Weigel, Ed.), Prentice Hall, 1970.

43. Study Group for the Seismic Design of Timber Structures. Newsletter No. 1. Min. of Works and Development. Hamilton, New Zealand, 1982.

44. Thurston, S.J. Cyclic Loading of Large Timber T-Joints Incorporating Nailed steel Side Plates. Report 5-79/6. Ministry of Works and Development, Wellington, New Zealand, 1979 .

45. Timber Design Manual, Laminated Timber Institute of Canada, 1980.

46. Tissell, J.R. \& J.R. Elliott, Plywood Diaphragms, Research. Report 138. American Plywood Association, 1982 .

47. Walford, G.B. Derivation of Design Loads for Timber Fasteners. Newsletter No. 5:5-15, New Zealand Timber Design Society, 1981.

48. Wilkinson, T.L. Vibrational Loading of Mechanically Fastened Wood Joints, USDA For. Serv. Res. Paper FPL 274, 1976 .

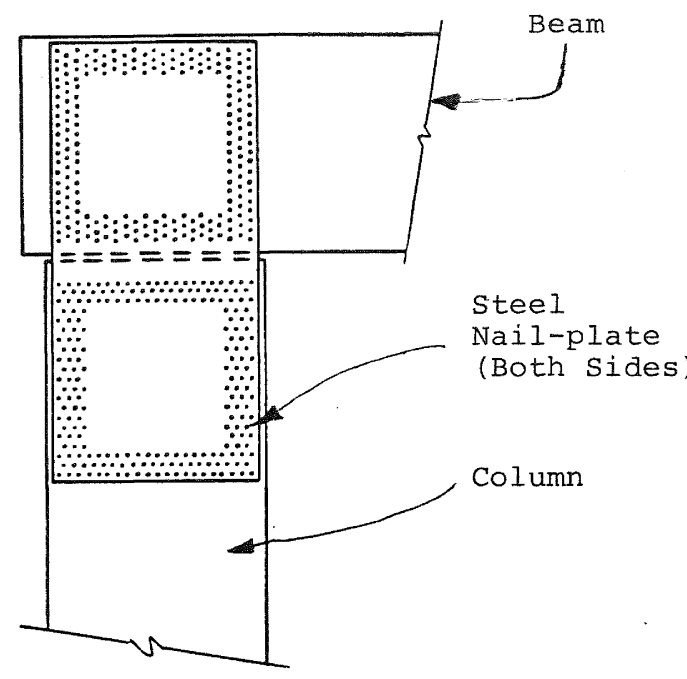

Beam-Column Connection

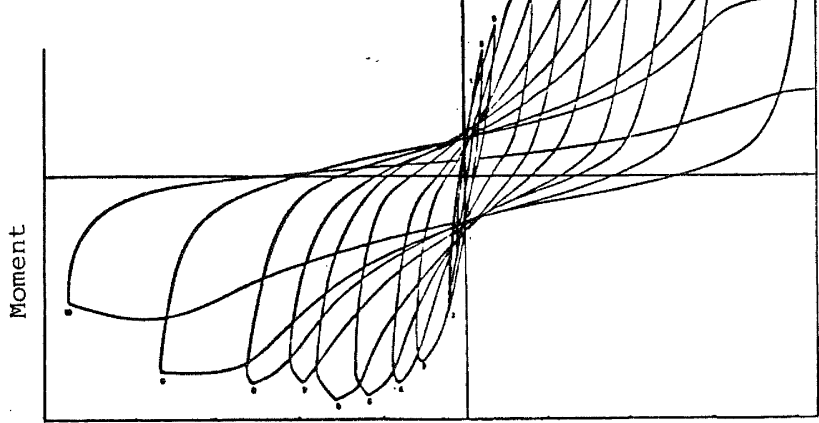

Rotation

Typical Hysteresis Curves

Figure 1: Moment Resisting Glulam Beam-Column Connection with Nailed Steel Side Plates

TABLE 1: Comparison of Structural Type Factors in Canadian and New Zealand Codes.

\begin{tabular}{|c|c|c|c|}
\hline Structure & Material & $\begin{array}{l}\text { Canada (31) } \\
\mathrm{K}\end{array}$ & $\begin{array}{l}\text { New Zealand (41) } \\
\text { SM }\end{array}$ \\
\hline Frames & $\begin{array}{l}\text { steel } \\
\text { reinforced concrete } \\
\text { wood }\end{array}$ & $\begin{array}{l}0.7 \\
0.7 \\
-\end{array}$ & $\begin{array}{ll}0.64 & \\
0.8 & \\
1.2 & \text { Ductile } \\
1.5 & \text { Limited ductility } \\
2.4 & \text { No ductility }\end{array}$ \\
\hline Walls & $\begin{array}{l}\text { reinforced concrete } \\
\text { wood }\end{array}$ & $\begin{array}{l}1.0 \\
1.0\end{array}$ & $\begin{array}{l}1.0 \\
1.0 \text { Nailed sheathing } \\
1.2 \text { Glued Sheathing }\end{array}$ \\
\hline $\begin{array}{l}\text { Diagonally } \\
\text { Braced } \\
\text { Systems }\end{array}$ & $\begin{array}{l}\text { steel } \\
\text { reinforced concrete } \\
\text { wood }\end{array}$ & $\begin{array}{l}1.3 \\
1.3 \\
1.3\end{array}$ & $\begin{array}{l}2.0 \\
2.5 \\
1.7 \text { Ductile end } \\
\text { connections } \\
2.0 \text { Limited ductility }\end{array}$ \\
\hline
\end{tabular}

